\title{
Sources, degradation and recycling of organic matter associated with sinking particles in Lake Michigan
}

\author{
Philip A. Meyers ${ }^{1}$ and Brian J. Eadie ${ }^{2}$ \\ 'Department of Geological Sciences and Center for Great Lakes and Aquatic Studies, The University of \\ Michigan, Ann Arbor, MI 48109-1063 and ' ${ }^{2}$ Great Lakes Environmental Research Laboratory, National \\ Oceanic and Atmospheric Administration, Ann Arbor, MI 48105, U.S.A.
}

(Received 3 March 1992; accepted in revised form 28 September 1992)

\begin{abstract}
Sediment trap material collected at five depths from two locations in Lake Michigan has been studied to determine the sources of particulate organic matter and the early diagenetic changes which occur during sinking of particles. Aquatic material dominates in shallower depths whereas land-derived material is more important in near-bottom depths. Organic carbon concentrations decrease with depth as a result of remineralization of organic matter by microbial activity and dilution by resuspended bottom sediments. Preferential remineralization of algal organic matter and downslope transport of particulate matter from coastal areas create differences in the lipid biomarker characteristics of settling particles found at different depths in the water column. Calculations of apparent decomposition rate constants from lipid distributions at different depths show that shorter chainlength $n$-alkanoic acids are degraded faster than longer components. Carbon and nitrogen isotopic compositions of total organic matter are nearly unaffected by large-scale amounts of remineralization during sinking.
\end{abstract}

Key words-sediment traps, carbon isotopes, nitrogen isotopes, $n$-alkanes, $n$-alkanoic acids, decomposition rate constants, lake sediments

\section{INTRODUCTION}

Organic matter is an especially dynamic component of the nutritional, geochemical, and microbial cycles of lakes and oceans. Organic matter associated with sinking particles is subject to a variety of transformational and degradational processes in the relatively short time required to settle to bottom sediments. Sediment trap studies in lakes and oceans have shown that major decreases in the amount of organic matter accompany the sinking of particles. Eadie et al. (1984) estimate that $96 \%$ of the organic carbon produced in the photic zone of Lake Michigan is recycled before it can sink to the bottom only $100 \mathrm{~m}$ below, a value nearly as great as the $99 \%$ or more reported in deeper marine areas (e.g., Cobler and Dymond, 1980; Knauer et al., 1979; Suess, 1980; Knauer and Martin, 1981; Martin et al., 1987). The different components comprising organic matter have different susceptibilities towards degradation, which can result in progressive alteration of the composition of particulate organic matter during sinking. Plant pigments are exceptionally vulnerable to destruction, with as little as $1 \%$ of the original amount becoming buried in the sediments of Dabob Bay, Washington (Furlong and Carpenter, 1988). Sugars and amino compounds are also lost during sinking only $110 \mathrm{~m}$ to the bottom at this location, although some lignin components of vascular land plants experience essentially no changes (Hedges et al., 1988). Studies of lipid compositions of sediment trap contents from a variety of environments, including Lake Michigan (Meyers et al., 1980, 1984a; Gardner et al., 1989; Parrish et al., 1992), Dabob Bay (Prahl et al., 1980), and open-ocean areas (Wakeham et al., 1980; Wakeham, 1982; Wakeham and Lee, 1989), have shown, furthermore, that lipid material contributed from aquatic organisms is remineralized more quickly than is total organic matter, whereas some land-derived lipid components appear to survive better.

The results of our earlier studies in Lake Michigan have suggested a complex interaction of multiple sources, remineralization within the water column, and resuspension of bottom sediment which control the organic matter contents of particles sinking below the epilimnion (Meyers et al., 1980, 1984a; Eadie et al., 1984). Our earlier data have been from samples collected by sediment traps moored at two depths, one in the metalimnion and one in the hypolimnion, and they indicate that important changes occur to particulate organic matter during the early stages of sinking. Study of the epilimnion - the upper part of the water column - is therefore especially warranted. We also were concerned about the significance of resuspension of bottom sediment in the hypolimnion. We report here our results from study of the organic matter collected in sediment traps positioned at five depths throughout the water column at two locations in Lake Michigan. 


\section{SAMPLES AND PROCEDURES}

\section{Study area}

The Laurentian Great Lakes, which include Lake Michigan, have surface areas that are nearly as large as their drainage basins. Aquatic sources of organic matter are therefore important. Andren and Strand (1981) estimate that $95 \%$ of the total supply of organic carbon to Lake Michigan is from aquatic productivity and that the remainder is equally divided between eolian and fluvial sources. They further estimate that only $4 \%$ of the supply becomes incorporated into bottom sediments, which means that most of the algal organic matter is remineralized within the water column.

Differences exist in the amounts and types of organic matter delivered to the waters of the northern and southern portions of Lake Michigan. The northern area is surrounded by a predominantly forested, rural watershed. Except for the Fox River, which flows into Green Bay and not directly into the lake, the rivers in the northern half of the lake are small. The southern part has a watershed having large population centers, industrial areas, and much farming. Large rivers drain runoff from these land areas directly into the southeast part of the lake from the state of Michigan. Lake Michigan is oligotrophic, yet its southern portion has a measurably higher productivity than the northern part, largely because of the differences in nutrient supply from drainage areas (cf. Mackin et al., 1980, and references therein).

We selected two locations in Lake Michigan for study, one in the northern basin and one in the southern basin (Fig. 1). Our study areas were located in the axial center of the lake to minimize the effects of local sources of land runoff and to be positioned in deep water so that resuspension of bottom sediments by wave turbulence was less likely.

Samples

Settling particulate material was collected in sediment traps deployed during the summer and early fall of 1980. Material was obtained from five depths within the water column at each of the two locations in Fig. 1. Station 11 was sited in $171 \mathrm{~m}$ of water in the northern part of the lake. Trap depths of 11, 31, 91,146 , and $166 \mathrm{~m}$ were used at this location. The deployment period totalled 126 days, from 25 June to 29 October. The trap string at Station 4 in the southern basin was moored in $145 \mathrm{~m}$ of water. The sampling depths were $15,35,80,120$, and $140 \mathrm{~m}$. The traps here were deployed on 18 June and retrieved on 7 November, a total of 142 days.

Lake Michigan typically remains thermally stratified throughout this period, with the thermocline residing at around $30-35 \mathrm{~m}$ at its strongest development. Both trap moorings consequently collected settling particles from the epilimnion ( 11 or $15 \mathrm{~m}$ ), within the metalimnion $(31$ or $35 \mathrm{~m})$ and the hypolimnion (deeper than $35 \mathrm{~m}$ ).
The traps, described by Eadie et al. (1984), consisted of cylinders $50 \mathrm{~cm}$ long by $10 \mathrm{~cm}$ in diameter. The $500 \mathrm{ml}$ sample collection bottle at the bottom of each trap was prefilled with distilled water poisoned with $100 \mathrm{mg} \mathrm{HgCl}_{2}$ to arrest bacterial and faunal activity and thereby to improve preservation of organic matter. Lee et al. (1992) have confirmed that mercuric chloride is an effective bacteriostat in sediment trap experiments. Samples were kept frozen after recovery from the traps and were freeze-dried within several months of collection.

\section{Analysis}

Our work on these samples has been done over a number of years since they were obtained in 1980 . Organic carbon and lipid content analyses were completed in 1984. Isotopic measurements and flux calculations were done in 1991. Details are given later.

Organic carbon contents of the freeze-dried sediment trap material were determined by combustion of HCl-treated, carbonate-free samples in a Hewlett Packard $185 \mathrm{CHN}$ analyzer. The concentrations of organic carbon were calculated on a dry-weight basis for the original carbonate-containing material. Organic matter atomic $\mathrm{C} / \mathrm{N}$ ratios were obtained from the CHN analysis.

Organic carbon stable isotope ratios of the carbonate-free material were measured using a VG Micromass 602 spectrometer calibrated with NBS-20

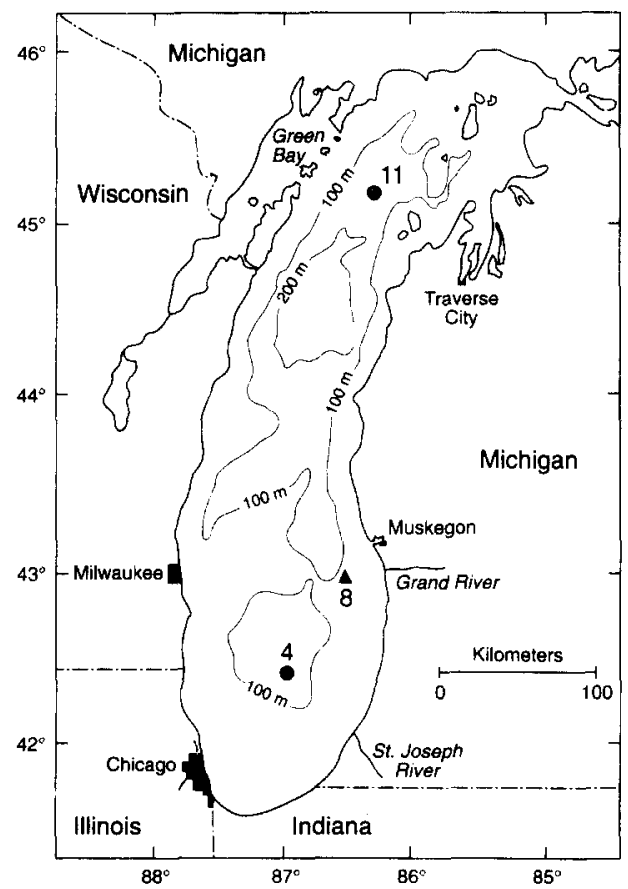

Fig. 1. Locations of sediment trap stations in Lake Michigan. Data discussed in this report are from the five-trap moorings at stations 4 and 11 which were deployed for the summer stratified period of 1980 . Results from station 8 , a two-trap mooring during the summer of 1978 (Meyers et al., 1984) are compared to the station 4 results. 
(carbonate) and NBS-21 (graphite) standards. Combustion of the carbonate-free organic matter was done at $900^{\circ} \mathrm{C}$ in sealed Vycor tubes in the presence of $\mathrm{CuO}$ and $\mathrm{Cu}$. Data are corrected for ${ }^{17} \mathrm{O}$ and expressed in conventional $\delta^{13} \mathrm{C}$ notation relative to the PDB standard. Nitrogen stable isotopes were measured with a VG Prism mass spectrometer and are reported relative to air.

Lipid contents of the freeze-dried trap samples were extracted into toluene/methanol, $2 / 1$, in a Soxhlet apparatus for $24 \mathrm{~h}$. Fatty acids were converted to their methyl esters by heating in the presence of methanolic $\mathrm{BF}_{3}$ (cf. Meyers and Takeuchi, 1979) prior to separation of the lipid fractions by silica gel column chromatography. The fractions which were separated and analyzed were saturated hydrocarbons, fatty acid methyl esters, and fatty alcohols. The latter were converted to their silyl ethers by treatment with BSTFA for subsequent analysis.

On column injection gas-liquid chromatography was used to identify the types and amounts of compounds present in the lipid fractions. A Hewlett Packard 5830 FID gas chromatograph equipped with a $20 \mathrm{~m}$ SE54 fused silica capillary column was employed. A measured amount of $\alpha$-cholestane was added to each sample fraction after column chromatography and before gas chromatography to quantify its components. This compound has been selected to avoid co-elution with any other compound in these lipid fractions. Individual compounds are tentatively identified by comparison of their retention times to those of authentic standards. Corrections have been made for instrumental mass discrimination over the wide range of surveyed lipid molecular weights and for the small amount of laboratory contamination which was determined from blank analyses.

\section{Estimation of fluxes and decomposition rates}

Average mass fluxes and sinking particles were calculated by dividing the dry weight of material collected in each trap by the number of days of the collection period and the $78.5 \mathrm{~cm}^{2}$ area of the trap. Organic carbon mass fluxes were determined by multiplying the average particle mass flux by the percentage of carbon contained in each sample.

Apparent decomposition rate constants for the hypolimnion were calculated using the difference between material analyzed in sediment traps moored at 35 and $80 \mathrm{~m}$ in the southern basin and 31 and $91 \mathrm{~m}$ in the northern basin. The $35 \mathrm{~m}$ traps were below the thermocline and collected materials that had passed through the zone of intense recycling within the epilimnion (Eadie et al., 1984). The deep traps selected at each station were above the regions of major sediment resuspension. An average settling velocity of $1 \mathrm{~m} /$ day, determined from radionuclide measurements and transport models of hydrophobic organic compounds (Eadie et al., 1989; Robbins and Eadie, 1991), was used in these calculations.

\section{RESULTS AND DISCUSSION}

Both similarities and differences exist in the bulk organic matter collected in the sediment traps deployed in the northern and southern basins of Lake Michigan. At both locations, the concentration of total organic carbon (TOC) in the trap contents generally decreases with increasing water depth, although the $31 \mathrm{~m}$ trap at Station 11 interrupts the trend by having a particularly high TOC of nearly $46 \%$ (Table 1). Particle mass fluxes at both stations increase with depth much more than the TOC concentrations decrease, so the TOC fluxes also generally increase with depth. The higher mass fluxes deeper in the water column result largely from resuspension of bottom sediments (cf. Eadie et al., 1984; Eadie and Robbins, 1987), with possible additional contribution from materials settling from the midwater turbidity plume which exists in the region of the thermocline in Lake Michigan (Chambers and Eadie, 1981; Harrsch and Rea, 1982). The TOC percentage decrease reflects both dilution of organic matter by resuspended superficial sediments, which typically have organic carbon concentrations substantially lower than those of settling sediments (average of $1-2 \%$, Rea et al., 1981), and the accumulating effect of continued

Table I. Elemental and isotopic compositions of organic matter associated with sinking particles at two locations in Lake Michigan

\begin{tabular}{|c|c|c|c|c|c|c|}
\hline $\begin{array}{l}\text { Sediment trap } \\
\text { Location and depth } \\
(\mathrm{m})\end{array}$ & $\begin{array}{l}\text { TOC } \\
(\%)\end{array}$ & $\begin{array}{c}\text { Atomic } \\
\mathrm{C} / \mathrm{N}\end{array}$ & $\begin{array}{l}\delta^{13} \mathrm{C} \\
(\%)\end{array}$ & $\begin{array}{l}\delta^{15} \mathrm{~N} \\
(\% 0)\end{array}$ & $\begin{array}{c}\text { Particle flux } \\
\left(\mathrm{g} / \mathrm{m}^{2} / \text { day }\right)\end{array}$ & $\begin{array}{c}\text { TOC flux } \\
\left(\mathrm{mg} / \mathrm{m}^{2} / \text { day }\right)\end{array}$ \\
\hline \multicolumn{7}{|l|}{ Station 4} \\
\hline 15 & 16.0 & 19.8 & -27.7 & 5.2 & 0.40 & 64 \\
\hline 35 & 14.2 & 22.5 & -28.8 & ND & 0.49 & 70 \\
\hline 80 & 6.4 & 8.7 & -26.8 & 3.6 & 0.97 & 62 \\
\hline 120 & 4.8 & 10.7 & -26.2 & 4.3 & 1.94 & 93 \\
\hline 140 & 8.8 & 21.2 & -26.6 & ND & 3.74 & 329 \\
\hline \multicolumn{7}{|l|}{ Station 11} \\
\hline 11 & 38.1 & 13.1 & -29.2 & ND & 0.07 & 27 \\
\hline 31 & 45.8 & 20.9 & -28.1 & ND & 0.26 & 119 \\
\hline 91 & 10.9 & 16.5 & -27.5 & ND & 0.41 & 45 \\
\hline 146 & 4.8 & 8.1 & -27.4 & 3.3 & 0.56 & 27 \\
\hline 166 & 5.7 & 13.3 & -27.8 & 3.3 & 1.15 & 66 \\
\hline
\end{tabular}

Fluxes are calculated for the period of sediment trap deployment during the summer stratification of 1980. TOC $=$ total organic carbon. ND $=$ not determined. 
remineralization during sinking to progressively deeper depths.

The particle mass flux is markedly higher at all levels in the southern trap array than in the northern one. The difference in water depth, $145 \mathrm{~m}$ as opposed to $171 \mathrm{~m}$, contributes to some of this contrast inasmuch as turbulent resuspension of bottom material is greater in shallower water than in deeper areas. The primary cause, however, is from the greater amount of fine-sized particles delivered to the southern basin by rivers. The small grain size of these clastic particles permits them to travel far into the lake and to be easily resuspended before finally sinking to the bottom. The larger supply of mineral sediment particles dilutes the TOC concentrations of the traps in the southern location (Table 1). The TOC mass fluxes nonetheless show that the total amount of organic carbon associated with sinking particles is greater in the southern traps than in the northern ones. This difference is consistent with the larger fluvial supply of nutrients and organic matter from land areas in the south (Mackin et al., 1980).

Eight of the 10 organic matter $\mathrm{C} / \mathrm{N}$ ratios are between 10 and 23 (Table 1) and are notably larger than the values of $7-10$ found in sediment trap materials from the more productive coastal area close to the mouth of the Grand River (Meyers et al., 1984a). C/N values above about 15 generally indicate dominance of land vascular plant, as opposed to algal, debris in modern sedimentary material. The epilimnion trap from Station 11 in the northern basin has a $\mathrm{C} / \mathrm{N}$ ratio of 13 , which suggests that land-derived organic matter makes a smaller contribution to near-surface particulate material at this location, whereas the epilimnion trap at Station 4 has a $\mathrm{C} / \mathrm{N}$ value of $c a 20$. The contrast in $\mathrm{C} / \mathrm{N}$ values of these two shallow trap samples is consistent with the larger fluvial sources of particulate matter to the southern parts of Lake Michigan than to the northern parts. The mean $\mathrm{C} / \mathrm{N}$ values of the five traps at each location, however, are virtually the same, being only slightly higher (16.6) at Station 4 than at Station 11 (14.4). This similarity suggests that lateral supplies of particulate organic matter can occur deeper in the water column. The nature of these postulated subsurface contributions of organic matter is different at the two locations. $\mathrm{C} / \mathrm{N}$ ratios of 8.7 and 10.7 suggest that algal material is introduced to traps at Station 4 , whereas values of 20.9 and 16.5 imply land-derived material is added to the downward fluxes at Station 11.

Organic carbon stable isotope ratios change little with depth at both locations. At Station 4, values of $\delta^{13} \mathrm{C}$ are between -26.2 and $-28.8 \%$, and at Station 11 , the $\delta^{13} \mathrm{C}$ remains between -27.4 and $-29.2 \%$ (Table 1). The $\delta^{13} \mathrm{C}$ values of plankton tow matter from Lake Michigan are between -27 and $-29 \%$, as are the isotope values of land-derived C3 plant debris (Sackett, personal communication). The isotope ratios consequently cannot be used to distinguish between aquatic and land origins of organic matter in this situation. The $\delta^{13} \mathrm{C}$ values from Station 4 in the southern part of the lake have slightly heavier isotope values than those from the northern site. The three lower traps collected organic matter having an isotopic composition nearly the same as the $\delta^{13} \mathrm{C}$ of $-26 \%$ reported by Rea et al. (1980) for bottom sediments from a nearby core site $\left(42^{\circ} 20^{\prime} \mathrm{N}\right.$, $86^{\circ} 50^{\prime} \mathrm{W}$ ). Carbon isotope values become $c a 1 \%$ heavier with depth at both locations, although the ratios at the northern station are consistently lighter by $c a 1 \%$ than the southern values. Schelske and Hodell (1991) note higher productivity in Lake Ontario has created a shift towards heavier carbon isotope ratios in sedimentary organic matter. The slightly heavier $\delta^{13} \mathrm{C}$ values at Station 4 are consistent with higher rates of algal productivity in the southern basin of Lake Michigan. The pattern towards heavier $\delta{ }^{13} \mathrm{C}$ values with depth at both stations may reflect the appearance of organic matter that has moved laterally downslope from coastal regions of higher productivity.

It is interesting to note that a significant shift in carbon isotope signatures appears not to occur as particulate organic matter sinks in this lacustrine system despite the evident loss of a major fraction of initial organic carbon. The trend towards slightly heavier isotopic compositions with depth is in fact contrary to what would be expected from preferential losses of carbohydrates and proteins, which on average are isotopically heavier than total organic matter (Deines, 1980), and which have been reported to be especially vulnerable to remineralization during sinking in Dabob Bay, Washington (Hedges et al., 1988). The lack of distinctive isotopic source signatures of algal and land-derived organic matter in the Great Lakes ecosystem masks the explanation for this pattern by concealing isotopic evidence of selective degradation of material from one or the other of these principal sources.

The small amount of trap material available to this study limited determinations of $\delta^{15} \mathrm{~N}$ values to only half the trap samples. These values are in the range of 3.3-5.2\%. Pang and Nriagu (1977) report $\delta^{15} \mathrm{~N}$ values of phytoplankton in Lake Superior to average $1.6 \%$, whereas zooplankton and sedimentary organic matter had average $\delta^{15} \mathrm{~N}$ values of 5.7 and $5.0 \%$, respectively. Foodchain processing of organic matter commonly produces a several per mil shift in nitrogen isotope ratios at each trophic level (e.g. Fry, 1988), suggesting that the Lake Superior sedimentary organic matter was largely derived from phytoplankton and had been utilized by two or more trophic levels. The same type of processing probably occurs in Lake Michigan, and the sediment trap values in Table 1 appear to represent intermediate stages in this processing.

The compositions of the lipid fractions extracted from the sediment trap samples provide more detail about the sources of organic matter and the degree of 
Table 2. Concentrations and downward fluxes of $\boldsymbol{n}$-alkanes, $\boldsymbol{n}$-alkanoic acids, and $\boldsymbol{n}$-alkanols extracted from sinking particles collected at two locations in Lake Michigan during summer stratification, 1980

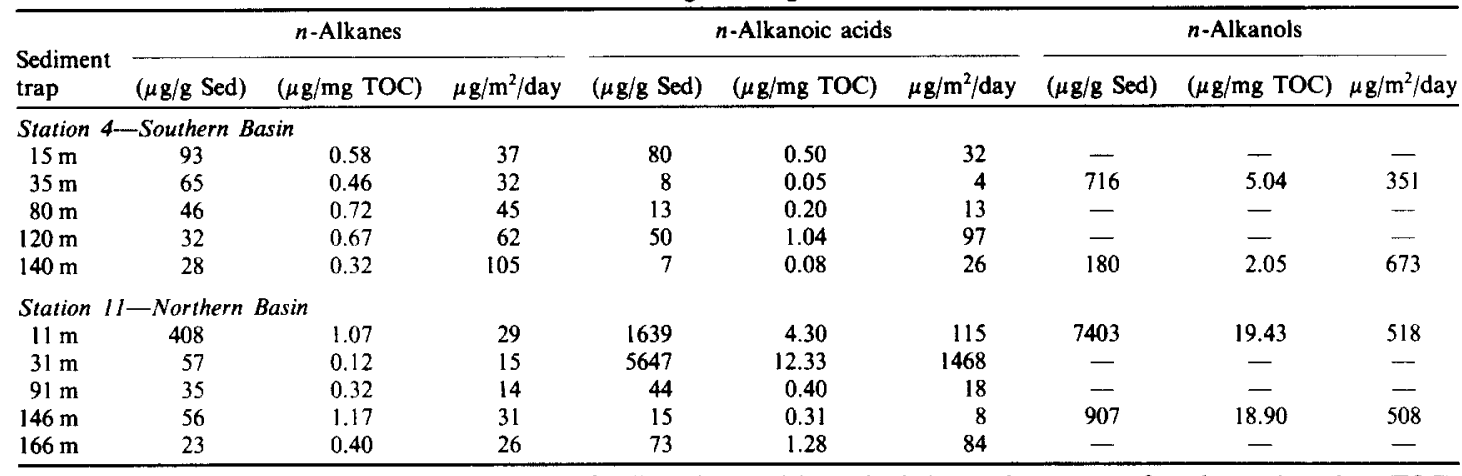

Concentrations are presented relative to dry weight of sedimenting particles and relative to the amount of total organic carbon (TOC).

alteration that has occurred. Concentrations of $n$ alkanes, $n$-alkanoic acids, and $n$-alkanols extracted from the sinking particles are presented in Table 2 in terms of dry sample weight and relative to TOC content. Concentrations of total lipids in zooplankton living in the Great Lakes range between 30 and $70 \%$ of dry weight (Cavaletto et al., 1989), and the total lipid contents reach as high as $50 \%$ in sediment trap material from central Lake Michigan (Parrish et al., 1992). In contrast, the concentrations of the saturated lipid components listed in Table 2 generally total less than $0.1 \%$ of the total organic matter in the trap samples. The extractable organic compounds cannot be considered representative of the bulk organic material in the sinking particles because of their low contributions to the total organic matter. The lipid molecules can, however, be useful and valid indicators of the transport and alteration processes acting on this fraction of the organic matter. By combining this information with the bulk characteristics of organic matter, a general understanding of the processes impacting all of the organic matter can be inferred.

The amounts of lipid components associated with the particles decreases more than their TOC contents do with increasing water depth (Table 2). Similar decreases in proportions of total lipid content are reported in sediment traps from Lake Huron and Lake Superior (Parrish et al., 1992). Concentrations of extractable $n$-alkanes show relatively consistent depth decreases at both stations, but concentrations of the $n$-alkanoic acids and from the limited number of $n$-alkanol determinations are erratic. $n$-Alkanes are generally considered to be less sensitive to degradation processes because these compounds lack the oxygen-containing functional groups and the double bonds that are susceptible to microbial attack. The $n$-alkane concentrations at both stations are similar, with the notable exception of sample 11-11 with its elevated concentration, but the $n$-alkanoic acids and $n$-alkanols differ. The contributions of the $n$ alkanes to the TOC are larger than the $n$-alkanoic acid contributions at Station 4 in the southern basin, which is the relationship expected from preservational considerations. This does not hold true at the northern location, however. The $n$-alkane proportion here is the lowest of the three lipid fractions. At both stations, the $n$-alkanols have the highest concentrations relative to TOC. All of the relative concentrations are lower than the concentrations reported by Meyers et al. (1984a) from the near-coastal area close to the mouth of the Grand River (see Fig. 1). The open-lake locations have lower productivity and are farther from fluvial sources of land-derived material, so this difference is reasonable.

In contrast to the downward decreases in absolute concentrations and in proportions to TOC, downward fluxes of total $n$-alkanes increase with depth at Station 4 and change little at Station 11 (Table 2). The $n$-alkane fluxes are controlled largely by the sediment particle fluxes, which increase markedly closer to the bottom at Station 4 and less so at Station 1 (Table 1). Resuspension and subsequent settling of bottom sediments evidently dilutes the absolute concentrations of these lipid components and exaggerates the apparent delivery rates in near-bottom traps. The flux rates of $n$-alkanoic acids (Table 2) appear to change little with depth at Station 4 while decreasing at Station 11. These lipid components are more susceptible to degradation during sinking than are the $n$-alkanes. The lack of much change in downward flux rates at Station 4 suggests that resuspension of bottom material, perhaps augmented by lateral supply from profundal areas, again exaggerates the apparent delivery to the lake bottom. The limited $n$-alkanol data, in which the near-bottom trap has the lowest concentration but the highest flux, support this interpretation of the station 4 flux rates.

Distributions of the individual $n$-alkane components (Fig. 2) are generally dominated by the longchain $\mathrm{C}_{27}$ and $\mathrm{C}_{29}$ waxy hydrocarbons which originate from trees and shrubs (Cranwell, 1973; Cranwell et al., 1987; Rieley et al., 1991) and which have been found to be the dominant $n$-alkanes in rain and snow in the American Midwest (Meyers and Hites, 1982). Differences exist in the distributions from the two locations. The $\mathrm{C}_{27} n$-alkane is the major component at three of the five depths at the northern 
station, but outweighs the $n-\mathrm{C}_{29}$ hydrocarbon only in Sample 4-120 at the southern site. Differences in $\mathrm{C}_{27} / \mathrm{C}_{29}$ predominances have been noted in cores of lake sediments (e.g., Cranwell, 1973; Meyers et al., 1984b) and appear to be related to changes in watershed forest types. The source information in this ratio has not been adequately evaluated, yet the forests around the northern part of Lake Michigan are dominated by conifers whereas the southern woodlands are primarily deciduous. Some difference in the type of land-derived plant waxes is expected, and this source-related signal could appear in the sediment trap contents.

The $\mathrm{C}_{31} n$-alkane is the major component of the hydrocarbon distribution in Sample 4-15 (Fig. 2). Cranwell et al. (1987) assign the origin of this compound to grasses, which are $\mathrm{C} 4$ plants and isotopically heavier than $\mathrm{C} 3$ plants. The $\delta^{13} \mathrm{C}_{\mathrm{org}}$ value in this sample is $-27.7 \%$ (Table 1 ), however, which rules out a large $\mathrm{C} 4$ contribution to the total organic matter. The location in the southern basin of Lake Michigan makes this site a good candidate to receive air-borne and fluvial pollen from farmlands to the west in Illinois and Wisconsin. This postulated contribution of $\mathrm{C} 4$ plant matter evidently appears only in the lipid contents of particulate organic matter at this location in the lake.

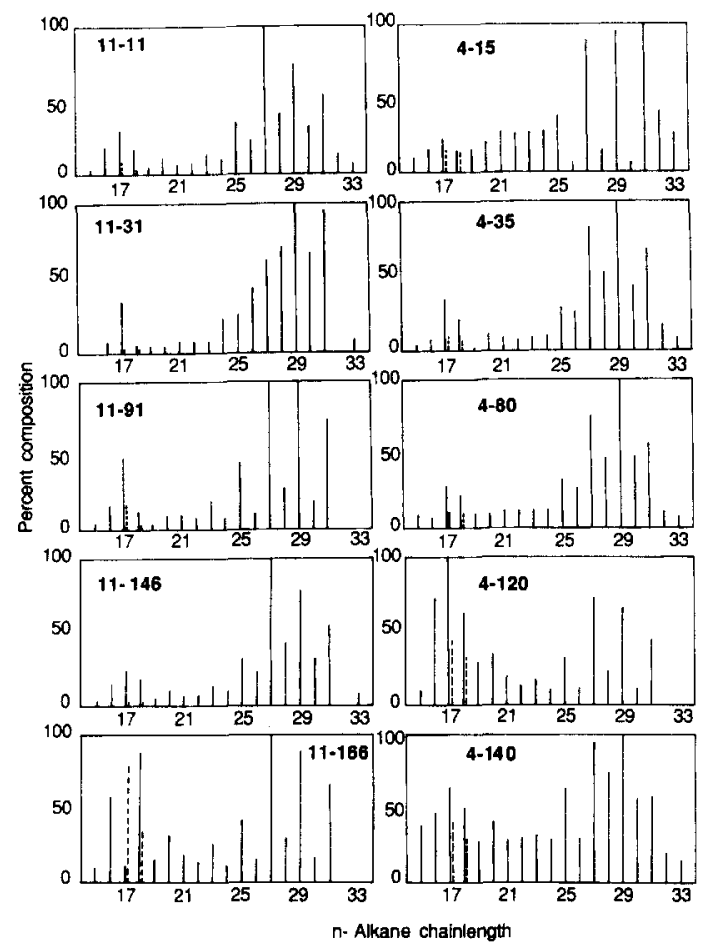

Fig. 2. Distributions of $n$-alkanes extracted from contents of sediment traps deployed in Lake Michigan, 1980. Contributions are expressed relative to the largest component. $(--)$ near $\mathrm{C}_{17}$ and $\mathrm{C}_{18}$ represent the isoprenoid alkanes pristane and phytane, respectively. Samples are identified as station-depth in meters below the lake surface. Total water depths are $145 \mathrm{~m}$ at station 4 and $171 \mathrm{~m}$ at station 11 .
The hydrocarbon distributions in the two deeper traps at Station 4 and the deepest trap at Station 11 contain large proportions of shorter chainlength components indicative of algal origin (Fig. 2). The $C_{17}$ $n$-alkane, produced by phytoplankton (cf. Blumer $e t$ al., 1971; Giger et al., 1980) is the dominant component in the distribution of Sample 4-120 and an important contributor to Sample 4-140. The proportional contributions of the isoprenoid hydrocarbons pristane and phytane are also large in these three deeper samples. Pristane is produced primarily in the digestive tracts of copepods from phytol, the alcohol sidechain of chlorophyll a (Blumer et al., 1971). Phytane is produced by anaerobic microbial reprocessing of phytol (cf. Risatti et al., 1984). The presence of both these derived hydrocarbons in the contents of the deeper traps is further evidence of early diagenetic alteration of algal debris while sinking to the bottom of Lake Michigan. The presence of large proportions of the algal $\mathrm{C}_{17} n$-alkane in the deeper traps intimates that sinking of organic matter to the lake bottom is augmented by lateral or downslope supply. Downslope transport from more productive coastal areas, followed by resuspension and resettling, is a possible route. Interception of the algal hydrocarbons by the deeper sediment traps which, like all the traps, contained mercuric chloride may have enhanced preservation of these compounds relative to organic matter which slowly sank to the lake bottom. The presence of the algal hydrocarbons in the deeper traps contrasts with the findings of Goossens et al. (1989). They report that algal hydrocarbons, which dominate the particulate matter in the surface waters of Lake Vechten, The Netherlands, are degraded during sinking and early deposition to the extent that they are minor components of the sediments of this shallow lake. The deeper traps may therefore provide evidence that rapid sinking and lateral transport of particles may improve preservation of organic matter.

The source character of the $n$-alkanoic acid molecular distributions of the sediment trap samples contrasts markedly with that of their $n$-alkane contents. Whereas the chainlength distributions of the hydrocarbons indicate large contributions of landplant lipids and record different transport routes at different depths, the fatty acid compositions are made up mostly of shorter chainlength components and show few differences related to depth or location in the lake (Fig. 3). The $\mathrm{C}_{16} n$-alkanoic acid that dominates all of the distributions is a ubiquitous component of all biota. The diminished importance of land-plant waxes, which include the $\mathrm{C}_{24}, \mathrm{C}_{26}$, and $\mathrm{C}_{28}$ compounds evident in some of the distributions in Fig. 3, indicates that the fatty acid compositions have been altered during their transport to the sediment traps. The small contributions of algal hydrocarbons in most of the trap contents makes algal contributions of the more degradable fatty acids an unlikely dilutant of the land-sourced lipids. The most 


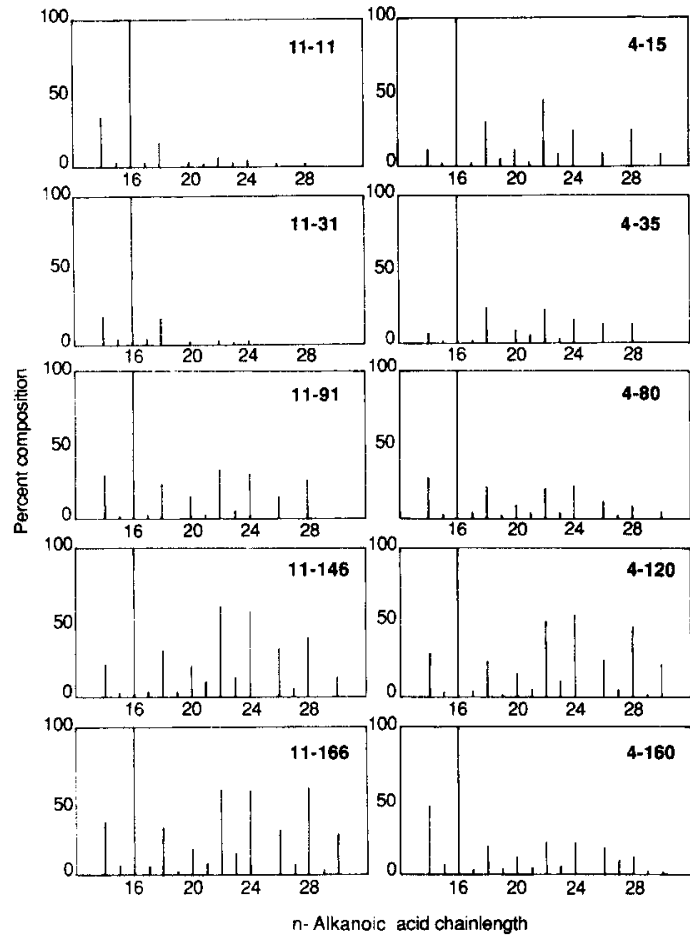

Fig. 3. Distributions of $n$-alkanoic acids extracted from contents of sediment traps deployed in Lake Michigan, 1980. Contributions are expressed relative to largest component. Samples are identified as station-depth in meters below the lake surface. Total water depths are $145 \mathrm{~m}$ at station 4 and $171 \mathrm{~m}$ at station 11 .

probable alteration is from microbial replacement of the original algal and land-plant fatty acid contents of the settling particles with microbial acids. Microbes produce abundant $n$-alkanoic acids and $n$ alkanols, but few $n$-alkanes, which is why their products can appear in one lipid fraction but not another.

The use of ratios of selected indicator lipid components makes comparisons of the different distributions shown in Figs 2 and 3 easier. The ratio of long chainlength, land-plant components to short chainlength, algal components is one useful parameter. Such ratios for the compositions of $n$-alkanes, $n$-alkanoic acids, and $n$-alkanols give seemingly contradictory source information (Table 3). The $n$ alkane ratios are generally fairly high, in the range of 5-7, and indicate land-plant origins for this lipid fraction. The contents of the two deeper traps at Station 4 have low ratios, consistent with the larger algal input evident in Fig. 2. The deeper $n$-alkanol long/short ratios are high, like those of the landderived $n$-alkane. In contrast, the $n$-alkanoic acid long/short ratios are low, making land-derived components minor parts of these lipid fractions.

Biosynthetic pathways produce straightchain lipids in which the number of atoms in the carbon chains are enzymatically controlled. Biological $n$-alkanes consequently contain predominantly odd-numbered carbon chains, whereas $n$-alkanoic acids and $n$ alkanols have even-numbered chains. Slow-acting diagenetic alterations of the carbon chains in sediments gradually erase this characteristic of freshly synthesized lipid matter. The odd/even ratios of $n$-alkanes in the sediment trap contents are diminished significantly from the values between 8 and 28 which typify fresh land-plant waxy hydrocarbons (Rieley et al., 1991), yet they remain greater than one. Weathering during transport from land sources is a probable cause for at least some of the decrease. The even/odd radios of the $n$-alkanoic acids are markedly higher than the hydrocarbon ratios. Furthermore, these ratios are greater than the leaf-wax values of 8-14 reported by Rieley et al. (1991). These differences imply that the fatty acids have been more recently synthesized than the hydrocarbons. Microbial production during settling of particles is the most likely explanation. The $n$-alkanoic acid even/odd ratios diminish with depth, which suggests that microbial activity is most intense in the epilimnion and metalimnion. This observation agrees with Eadie et al. (1984), who have estimated that over $80 \%$ of the organic matter produced in the photic zone of Lake

Table 3. Ratios of lipid components in sinking particles collected at two locations in Lake Michigan during summer stratification, 1980

\begin{tabular}{|c|c|c|c|c|c|c|}
\hline \multirow{2}{*}{$\begin{array}{l}\text { Sediment } \\
\text { trap }\end{array}$} & \multicolumn{2}{|c|}{$n$-Alkanes } & \multicolumn{2}{|c|}{$n$-Alkanoic acids } & \multicolumn{2}{|c|}{$n$-Alkanols } \\
\hline & Long/short* & Odd/even & Long/short $\dagger$ & Even/odd & Long/short $\dagger$ & Even/odd \\
\hline \multicolumn{7}{|c|}{ Station 4 -Southern Basin } \\
\hline $15 \mathrm{~m}$ & 5.6 & 2.4 & 0.42 & 147 & - & - \\
\hline $35 \mathrm{~m}$ & 6.2 & 1.7 & 0.33 & 21.6 & 3.4 & 4.4 \\
\hline $80 \mathrm{~m}$ & 5.0 & 1.7 & 0.27 & 11.1 & - & - \\
\hline $120 \mathrm{~m}$ & 1.3 & 1.6 & 0.83 & 11.3 & - & - \\
\hline $140 \mathrm{~m}$ & 1.9 & 1.3 & 0.32 & 8.3 & 7.7 & 4.8 \\
\hline \multicolumn{7}{|c|}{ Station II-Northern Basin } \\
\hline $11 \mathrm{~m}$ & 6.0 & 1.8 & 0.04 & 17.4 & 0.16 & 8.8 \\
\hline $31 \mathrm{~m}$ & 7.0 & 1.3 & 0.01 & 17.7 & - & - \\
\hline $91 \mathrm{~m}$ & 5.0 & 3.6 & 0.47 & 28.2 & - & - \\
\hline $146 \mathrm{~m}$ & 7.3 & 1.9 & 0.85 & 9.1 & 6.7 & 3.7 \\
\hline $166 \mathrm{~m}$ & 7.1 & 1.4 & 0.86 & 9.3 & - & - \\
\hline
\end{tabular}

Long/short ratios represent land/aquatic components. Higher odd/even alkane and even/odd acid and alkanol ratios indicate greater retention of biological carbon chainlengths or more recent biosynthesis of these lipid components.

$*\left(\mathrm{C}_{27}+\mathrm{C}_{29}+\mathrm{C}_{31}\right) /\left(\mathrm{C}_{15}+\mathrm{C}_{17}+\mathrm{C}_{19}\right)$.

$+\left(C_{24}+C_{26}+C_{28}\right) /\left(C_{14}+C_{16}+C_{18}\right)$ 
Michigan is remineralized before sinking to the hypolimnion. Moreover, the lipid data indicate that the degradability of the surviving organic matter decreases with greater depth.

The smallest values of the acid long/short ratio appear in Samples 11-11 and 11-31, which have elevated concentrations of TOC (Table 1), of $n$ alkanoic acids (Table 2), and nearly identical even/odd ratios (Table 3). Furthermore, the $n$-alkanol long/short ratio of Sample 11-11 is very low (Table 3). The two sediment traps which provided these samples were located in the northern part of Lake Michigan and evidently collected low fluxes of particles rich in algal organic matter. The absence of algal $n$-alkanes indicates that the organic matter was subsequently microbially reworked. The high concentrations of TOC and of lipid components in these two traps result from additions of diluting clastic material from land that are minor at this location in comparison to Station 4 in the south, as verified by the difference in sediment particle fluxes (Table 1).

Decomposition rate constants were estimated using a steady-state, first-order model for TOC and for the $n$-alkane and $n$-alkanoic acid fractions. The TOC decomposition constant for the southern station is $0.007 /$ day, whereas for northern lake Station 11 we calculated a rate of $0.011 /$ day from our data and a rate of $0.014 /$ day from data obtained at a nearby location in 1984 by Parrish et al. (1992). The average of these decomposition rates for organic matter settling in the hypolimnion of offshore Lake Michigan is 0.011 day. The decomposition rate for $n$-alkanes between $\mathrm{C}_{14}$ and $\mathrm{C}_{33}$ is $0.004 /$ day in the hypolimnion of our two stations, substantially less than that of TOC. In the epilimnion, the $n$-alkane rate averages $0.030 /$ day, supporting our earlier evidence of intensive remineralization in the upper water column. Total $n$-alkanoic acids remineralize much more rapidly than TOC and especially $n$-alkanes. Their apparent decomposition constant from $14: 0$ to $32: 0$ averages $0.040 /$ day in the hypolimnion at Station 11, over four times that of TOC and 10 times that of the $n$-alkanes. This Lake Michigan alkanoic acid decomposition rate is of the same magnitude as the value of 0.060 /day we calculate from data collected from Lake Huron by Parrish $e t$ al. (1992).

Individual $n$-alkanes and $n$-alkanoic acids display a range of apparent decomposition constants as illustrated from Station 11 in Fig. 4. Rates decrease as carbon chainlength increases. The preferential degradation of the shorter chainlength $n$-alkanoic acids during sinking is similar to the chainlengthrelated degradation of acids observed by Haddad t al. (1992) in a sediment core from Cape Lookout Bight, although the water column rates we calculated are approx. 10 times those found in the coastal marine sediments. The $n$-alkane decomposition rates are more complex and appear to increase from negative values for short chainlengths to small positive values for longer chainlength alkanes. The negative

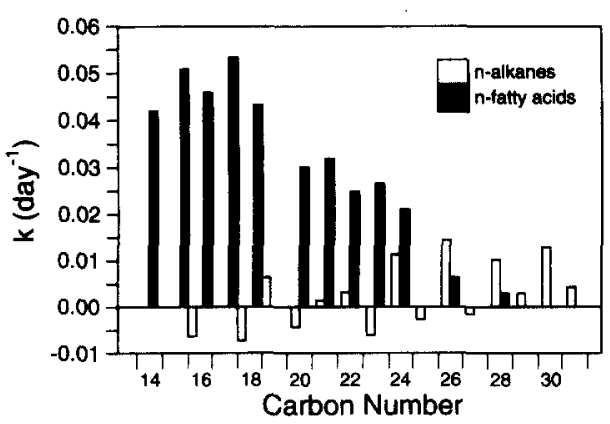

Fig. 4. Decomposition rate constants of individual $n$-alkanoic acids and $n$-alkanes estimated using a steady-state, first-order model and the difference between sediment trap contents at water depths of 31 and $91 \mathrm{~m}$ at Station 11 in northern Lake Michigan. Negative rate constants require sources of $n$-alkanes to the $91 \mathrm{~m}$ trap in addition to vertical sinking.

decomposition rates are a consequence of greater concentrations of the shorter components in near-bottom traps than in shallower traps. This implies that there is a significant source of these components other than from particles that settle downward during the summer stratified period. This source may involve resuspension or lateral transport of sediments, and it must be relatively rich in low molecular weight $n$-alkanes and depleted in $n$-alkanoic acids. The negative decomposition rates are consistent with delivery of organic matter to the deeper traps from more productive coastal areas by sinking and lateral transport of algal debris, as hinted by the $\delta^{13} \mathrm{C}$ patterns.

\section{SUMMARY AND CONCLUSIONS}

Comparisons of the types and amounts of organic matter associated with sinking particles collected at five depths at two locations in Lake Michigan provide new information about the cycling of organic carbon in this lake system. Sources of organic matter components can be identified, and generalized transport processes described. The extent of remineralization of particulate organic matter within the water column is also recognizable. Our results can be summarized as:

(1) Particulate organic matter is extensively reprocessed by microbes during sinking in Lake Michigan. The intensity of this activity is greatest in the epilimnion and metalimnion of this large, oligotrophic lake.

(2) The original algal and land-plant lipid character of particulate organic matter is partially replaced by secondary, microbial components as a result of the reworking during sinking.

(3) Substantial resuspension and resettling of bottom sediments occurs throughout the summer stratified period in the hypolimnion of Lake Michigan. Physical reworking of sediments redistributes associated organic matter from shallower areas to deeper areas and re-exposes organic matter to microbial and benthic utilization. 
(4) The microbial reprocessing and the resuspension of bottom sediments have little impact on the carbon isotopic composition of particulate organic matter. Limited data hint that nitrogen isotopes, however, may be affected by reprocessing.

(5) Land-derived lipid material is an important component of the extractable fraction of the settling organic matter in this large, oligotrophic lake. The southern part of the lake evidently receives more lipid matter from land areas by fluvial and eolian transport than is received by the northern part.

(6) Short chainlength $n$-alkanoic acids degrade at faster rates than do longer acids derived from landplant waxes during sinking to the bottom of Lake Michigan, thereby biasing the biomarker record of organic carbon sources.

Acknowledgements - We thank K. W. Dunham and P. L. Dunham for assisting in analysis of the samples and $\mathrm{K}$. C. Lohmann for providing the carbon isotope data. Portions of this research were supported by a NOAA grant to PAM. This is GLERL contribution number 803 .

\section{REFERENCES}

Andren A. W. and Strand J. W. (1981) Atmospheric deposition of particulate organic matter and polyaromatic hydrocarbons in Lake Michigan. In Atmospheric Pollutants in Natural Waters (Edited by Eisenreich S. J.), pp. 459-479. Ann Arbor Sciences, Ann Arbor.

Blumer M., Guillard R. R. L. and Chase T. (1971) Hydrocarbons of marine plankton. Mar. Biol. 8, 183-189.

Cavaletto J. F., Vanderploeg H. A. and Gardner W. S. (1989) Wax esters in two species of freshwater zooplankton. Limnol. Oceanogr. 34, 785-789.

Chambers R. L. and Eadie B. J. (198I) Nepheloid and suspended particulate matter in south-eastern Lake Michigan. Sedimentology 28, 439-447.

Cobler R. and Dymond J. (1980) Sediment trap experiment on the Galapagos spreading center, equatorial Pacific. Science 209, 801-803.

Cranwell P. A. (1973) Chain-length distribution of $n$ alkanes from lake sediments in relation to post-glacial environmental change. Freshwater Biol. 3, 259-265.

Cranwell P. A., Eglinton G. and Robinson N. (1987) Lipids of aquatic organisms as potential contributors to lacustrine sediments-II. Org. Geochem. 11, 513-527.

Deines P. (1980) The isotopic composition of reduced organic carbon. In Handbook of Environmental Isotope Geochemistry (Edited by Fritz P. and Fontes J. C), Vol. 1, pp. 329-406. Elsevier, Amsterdam.

Eadie B. J. and Robbins J. A. (1987) The role of particulate matter in the movement of contaminants in the Great Lakes. In Sources and Fates of Aquatic Pollutants (Edited by Hites R. A. and Eisenreich S. J.), Adv. Chem. Ser. No. 216, pp. 319-364. Am. Chem. Soc.

Eadie B. J., Chambers R. L., Gardner W. S. and Bell G. L. (1984) Sediment trap studies in Lake Michigan: resuspension and chemical fluxes in the southern basin. $J$. Great Lakes Res. 10, 307-321.

Eadie B. J., Vanderploeg H. A., Robbins J. A. and Bell G. L. (1989) The significance of sediment resuspension and particle settling. In Large Lakes: Ecological Structure and Function (Edited by Tilzer M. M. and Serruya C.), pp. 196-209, Springer, Berlin

Fry B. (1988) Food web structure on Georges Bank from stable $\mathrm{C}, \mathrm{N}$, and $\mathrm{S}$ isotopic compositions. Limnol. Oceanogr. 33, 1182-1190.
Furlong E. T. and Carpenter R. (1988) Pigment preservation and remineralization in oxic coastal marine sediments. Geochim. Cosmochim. Acta 52, 147-194.

Gardner W. C., Eadie B. J., Chandler J. F., Parrish C. C. and Malczyk J. M. (1989) Mass flux and "nutritional composition" of settling epilimnetic particles in Lake Michigan. Can. J. Fish. Aquat. Sci. 46, 1118-1124.

Giger W., Schaffner C. and Wakeham S. G. (1980) Aliphatic and olefinic hydrocarbons in recent sediments of Greifensee. Geochim. Cosmochim. Acta 44, 119-129.

Goossens H., Duren R. R., de Leeuw J. W. and Schenck P. A. (1989) Lipids and their mode of occurrence in bacteria and sediments-II. Lipids in the sediment of a stratified, freshwater lake. Org. Geochem. 14, $27-41$.

Haddad R. I., Martens C. S. and Farrington J. W. (1992) Quantifying early diagenesis of fatty acids in a rapidly accumulating coastal marine sediment. Advances in $\mathrm{Or}$ ganic Geochemistry 1991 (Edited by Maxwell J. et al.). Org. Geochem. 19, 205-216. Pergamon Press, Oxford

Harrsch E. C. and Rea D. K. (1982) Composition and distribution of suspended sediments in Lake Michigan during summer stratification. Environ. Geol. 4, 87-98.

Hedges J. I., Clark W. A. and Cowie G. C. (1988) Fluxes and reactivities of organic matter in a coastal marine bay. Limnol. Oceanogr. 33, 1137-1152.

Knauer G. A. and Martin J. H. (1981) Primary production and carbon-nitrogen fluxes in the upper $1500 \mathrm{~m}$ of the northeast Pacific. Limnol. Oceanogr. 26, 181-186.

Knauer G. A., Martin J.H. and Bruland K. W. (1979) Fluxes of particulate carbon, nitrogen and phosphorus in the upper water column of the northeast Pacific. DeepSea Res. 26A, 97-108.

Lee C., Hedges J. I., Wakeham S. G. and Zhu N. (1992) Effectiveness of various treatments in retarding microbial activity in sediment trap material and their effects on the collection of swimmers. Limnol. Oceanogr. 37, 117-130.

Mackin J. E., Owen R. M. and Meyers P. A. (1980) A factor analysis of elemental associations in the surface microlayer of Lake Michigan and its fluvial inputs. J. Geophys. Res. 85, 1563-1569.

Martin J. H., Knauer G. A., Karl D. M. and Broenkow W. W. (1987) VERTEX: carbon cycling in the northeast Pacific. Deep-Sea Res. 34, 27-285.

Meyers P. A and Hites R. A. (1982) Extractable organic compounds in Midwest rain and snow. Atmos. Environ. 16, 2169-2175.

Meyers P. A. and Takeuchi N. (1979) Fatty acids and hydrocarbons in surficial sediments of Lake Huron. Org. Geochem. 1, 127-138.

Meyers P. A., Edwards S. J. and Eadie B. J. (1980) Fatty acid and hydrocarbon content of settling sediments in Lake Michigan. J. Great Lakes Res. 6, 331-337.

Meyers P. A., Leenheer M. J., Eadie B. J. and Maule S. J. (1984a) Organic geochemistry of suspended and settling particulate matter in Lake Michigan. Geochim. Cosmochim. Acta 48, 443-452.

Meyers P. A., Kawka O. E. and Whitehead D. R. (1984b) Geolipid, pollen, and diatom stratigraphy in postglacial lacustrine sediments. Org. Geochem. 6, 727-732.

Pang P. C. and Nriagu J. O. (1977) Isotopic variations of the nitrogen in Lake Superior. Geochim. Cosmochim. Acta 41, 811-814.

Parrish C. C., Eadie B. J., Gardner W. S. and Cavaletto J. F. (1992) Lipid class and alkane distribution in settling particles of the upper Laurentian Great Lakes. Org. Geochem. 18, 33-40.

Prahl F. G., Bennett J. T. and Carpenter R. (1980) The early diagenesis of aliphatic hydrocarbons and organic matter in sedimentary particulates from Dabob Bay, Washington. Geochim. Cosmochim. Acta 44, 1959-1972.

Rea D. K., Bourbonniere R. A. and Meyers P. A. (1980) Southern Lake Michigan sediments: changes in 
accumulation rate, mineralogy, and organic content. J. Great Lakes Res. 6, 321-330.

Rea D. K., Owen R. M. and Meyers P. A. (1981) Sedimentary processes in the Great Lakes. Rev. Geophys. Space Phys. 19, 635-648.

Rieley G., Collier R. J., Jones D. M. and Eglinton G. (1991) The biogeochemistry of Ellesmere Lake, U. K.-I. source correlation of leaf wax inputs to the sedimentary record. Org. Geochem. 17, 901-912.

Risatti J. B., Rowland S. J., Yon D. and Maxwell J. R. (1984) Stereochemical studies of acyclic isoprenoidsXII. Lipids of methanogenic bacteria and possible contributions to sediments. In Advances in Organic Geochemistry 1983 (Edited by Schenck P. A. and de Leeuw J. W.), pp. 93-103. Pergamon Press, Oxford.

Robbins J. A. and Eadie B. J. (1991) Seasonal cycling of trace elements, Cs-137, Be-7 and Pu-239 +240 in Lake Michigan. J. Geophys. Res. 96, 17081-17104.
Schelske C. L. and Hodell D. A. (1991) Recent changes in productivity and climate of Lake Ontario detected by isotopic analysis of sediments. Limnol. Oceanogr. 36, 961-975.

Suess E. (1980) Particulate organic carbon flux in the oceans-surface productivity and oxygen utilization. Nature 288, 260-263.

Wakeham S. G. (1982) Organic matter from a sediment trap experiment in the equatorial North Atlantic: wax esters, steryl esters, triacylglycerols, and alkyldiacylglycerols. Geochim. Cosmochim. Acta 46, 2239-2257.

Wakeham S. G. and Lee C. (1989) Organic geochemistry of particulate matter in the ocean: the role of particles in oceanic sedimentary cycles. Org. Geochem. 14, 83-96.

Wakeham S. G., Farrington J. W., Gagosian R. B., Lee C. de Baar H., Nigrelli G. E., Tripp B. W.. Smith S. O. and Frew N. M. (1980) Organic matter fluxes from sediment traps in the equatorial Atlantic Ocean. Nature 286, $798-800$. 